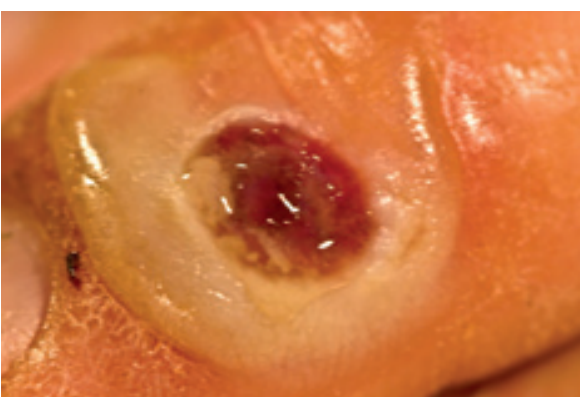

Figur 2 Kryoprosedyren etterlet eit krater

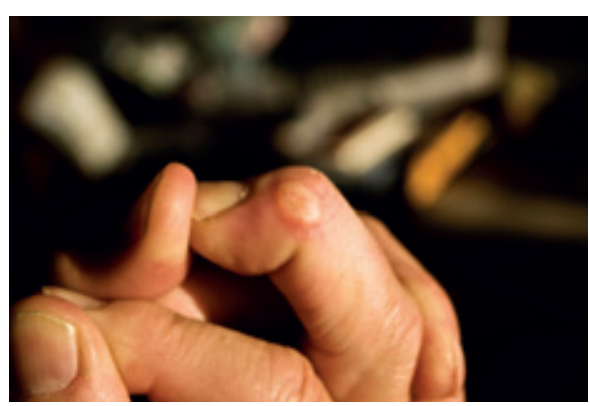

Figur 3 Kort etter epitaliseringa residiverte cysten

(nr. 11!). Då skjedde ting fort: Eg sat på ein stol med fingeren ut $i$ vêret, og resolutt vart cyste med omgivingar frosen ned med flytande nitrogen og cysten sneia vekk med skalpell i nivå med hudoverflata. Deretter vart området på nytt frose ned. Her var tydelegvis sterilitet/aseptikk eit ikkje-tema. Kontrasten til prosedyren ved plastikkirurgisk poliklinikk kunne ikkje ha vore større. Det vart lagt på ein bandasje, og eg fekk instruks om å bruke Brulidine-krem på såret.

Kryoprosedyren etterlet eit relativt stort nekrotisk krater (fig 2), og ein lymfeknute i aksillen vart svært øm. Den roa seg då eg gjekk over frå Brulidine til Fucidin-salve på såret.

Tre og ein halv månad etter at eg rapporterte til plastikkirurgen om residivet, fekk eg varsel om ny time. Men slik fingeren såg ut då, låg tilhøva ikkje til rette for meir kirurgi.

Fyrst etter 13 veker var området reepitelialisert etter kryokirurgien. Hadde dette vore i min yrkesaktive periode, hadde eg vore utelukka frå all kirurgisk aktivitet i over tre månader, noko som hadde fått ringverknader på arbeidsplassen. Kort tid etter epitelialiseringa residiverte cysten, med breiare basis enn før (fig 3).

\section{Avslutning}

Dette har kosta meg ikkje lite tid og pengar. Kva det har kosta helsevesenet, vågar eg ikkje tenkje på eingong. Dette må vere eit strålande døme på ineffektivitet $i$ eit overadministrert helsevesen. Kan det vere ei av årsakene til den såkalla legemangelen?
Sidan det såg ut som om norske helsevesenet hadde tømt sitt terapeutiske armamentarium, vurderte eg å reise ein stad der dei hadde røynsle med «tradisjonell medisin» og prøve med flaggermusblod eller noko slikt. Resultatet kunne neppe blitt dårlegare og ulempene neppe større.

Men så vart fingeren uforvarande utsett for eit traume så cysteinnhaldet vart hemoragisk - og cysten tok til å minke. Det førde tanken inn på ei behandling eg i si tid las om i mi nordiske «lærebog» i kirurgi (frå 1957): »...sprängning av cystan genom att hårt pressa den mot underlaget.»

Før i tida var det noko som heitte chirurgia minor, som distriktslegen ordna på kontoret. Ventetida var færre timar på venterommet enn månader $i$ dagens helsevesen. Men distriktslegen er som kjent ein utrydda rase.

I nemnde «lærebog» står det diverre: «Detta leder dog ofte til recidiv.» Så kanskje eg til slutt må prøve noko «alternativt» likevel?

\section{Otto Inge Molvær \\ marinmed@frisurf.no \\ 5555 Førde i Hordaland}

Manuskriptet ble mottatt 27.3. 2009 og godkjent

11.6. 2009. Medisinsk redaktør Erlend Hem.

\title{
Vurdering og behandling av tumor på hånd
}

Årsakene til tumor på hånden kan være mange, og det er derfor viktig at de som vurderer dette, innehar tilfredsstillende kompetanse slik at det blir håndtert riktig. Otto Inge Molværs sykehistorie er et godt eksempel på en medisinsk problemstilling som ikke er blitt tilfredsstillende vurdert og behandlet. Som han angir har dette medvirket til lang behandlingstid innen flere spesialiteter med en betydelig økonomisk kostnad både for pasient og helsevesen.

\section{Diagnostikk}

Ved vurdering av tumor på hånden må man i første omgang skille mellom godartede og ondartede forandringer. Dette er avgjørende i forhold til hastegrad for behandling og for hvilken prosedyre som skal benyttes. De godartede tumorene kan videre kategoriseres i cystiske og solide svulster. Er man usikker på diagnosen, bør den verifiseres med (eksisjons-) biopsi, alternativt kan det rekvireres MR- eller ultralydundersøkelse. Basert på Molværs sykehistorie med utvik- ling av en cystisk tumor og ut fra vedlagte bilder vil følgende differensialdiagnoser være aktuelle (1):

Synovialt ganglion. Dette er den hyppigst forekommede tumor på hånden, hvor leddvæske presses gjennom synovialmembranen og hvor det foreligger en ventilmekanisme som gjør at væsken ikke returneres. Mukoid cyste er en form for ganglion, men er assosiert med degenerativ leddsykdom. Den økte leddvæskeproduksjonen gir da utbuking av leddkapselen på det svakeste punktet, ofte ved proksimale neglevoll. Dette kan igjen føre til dystrofi av neglen. De mukoide cystene har også lettere for å rupturere spontant. Sannsynligvis er dette den riktige diagnosen hos Molvær. I dette tilfellet vil det derfor være mest korrekt å undersøke med røntgen for vurdering av degenerative forandringer som eventuelt bør behandles.

Epidermoid cyste (inklusjonscyste). Disse tumorene utvikles langsomt, oftest på palmarsiden, hvor spontan eller traumatisk betinget okklusjon av epidermale celler som produserer keratin eller andre epidermale produkter fører til en cystisk hevelse.

Andre godartede svulster på hånden. Det kan være kjempecellesvulst på seneskjeden (ofte traumatisk betinget og en relativt vanlig solid svulst), (dermato-) fibromer (ofte nodulære og faste svulster i hud), fremmedlegemereaksjoner/granulomer, pyogent granulom, nevrofibrom, Heberdens knuter ved artrose, vorter (verucca vulgaris), aktinsk keratose (kun mens forandringen var i tidlig fase, da dette er relativt flate lesjoner).

Ondartede svulster. Dette kan være plateepitelcellekreft, keratoakantom (potensiell malignitetsfare), basalcellekreft, amelanotisk melanom.

På bakgrunn av tumorens farge i dette tilfellet vil pigmenterte lesjoner som for eksempel malignt melanom og vaskulære lesjoner være mindre aktuelle.

\section{Behandling}

De ulike diagnosene innebærer forskjellig type behandling, og legen som behandler 
disse svulstene, bør derfor kjenne til alle disse alternativene i tillegg til å inneha god kjennskap til håndens anatomi. I praksis er det derfor rimelig at disse pasientene blir henvist til ortoped eller plastikkirurg.

Basert på at dette synes å være et synovialt ganglion eller en mukoid cyste vil behandlingsstrategien være som følger (2): I første omgang er man avventende, da det $i$ en del tilfeller vil forekomme spontan regresjon. Symptomgivende forandring, som smerte og begrenset bevegelighet, vil være indikasjon for behandling. Aspirasjon alene, som i dette tilfellet ble utført hos revmatologen, vil nesten alltid gi residiv. Kombinert med installasjon av kortikosteroider eller hyaluronidase er det i enkelte studier imidlertid vist relativt god behandlingseffekt, men også etter denne behandlingen, særlig ved mukoide cyster, ser man ofte residiv. Den kirurgiske behandlingen er ekstirpasjon av cysten med tilhørende stilk samt fjerning av en del av leddkapselen. Ved mukoide cyster vil det i tillegg være aktuelt å fjerne de degenerative forandringene i leddet, alternativt å utføre artrodese. Residivfrekvensen ved fjerning av cysten med stilk og leddkapsel er 10-20\% ved synoviale ganglioner og opp mot $30 \%$ ved mukoide cyster.

Kryobehandling vil, som hos Molvær, nesten alltid gi residiv og er derfor ikke riktig behandling. Imidlertid kan dette være en tilfredsstillende behandling på vorter og aktinske keratoser. Hadde det vært mistanke om en av de andre godartede tumorene, er behandlingen i utgangspunktet kirurgisk ekstirpasjon.

Ondartede svulster skal i utgangspunktet fjernes kirurgisk med en bestemt fri margin. Det kan deretter oppstå defekter som trenger hudtransplantat eller lappeplastikker. Ved større ondartede svulster vil det være aktuelt med amputasjon.

\section{Kim Alexander Tønseth}

kim@tonseth.no

Plastikkirurgisk avdeling

Oslo universitetssykehus, Rikshospitalet

0027 Oslo

Oppgitte interessekonflikter: Ingen

\section{Litteratur}

1. Hasham S, Burke FD. Diagnosis and treatment of swellings in the hand. Postgrad Med J 2007; 83: 296-300.

2. Athanasian EA. Ganglions and mucous cysts. I: Green DP, Hutchkiss RN, Petersson WC et al, red. Operative hand surgery. Bd. 2. 5. utg. New York: Churchill Livingstone, 2005: 2221-37. 